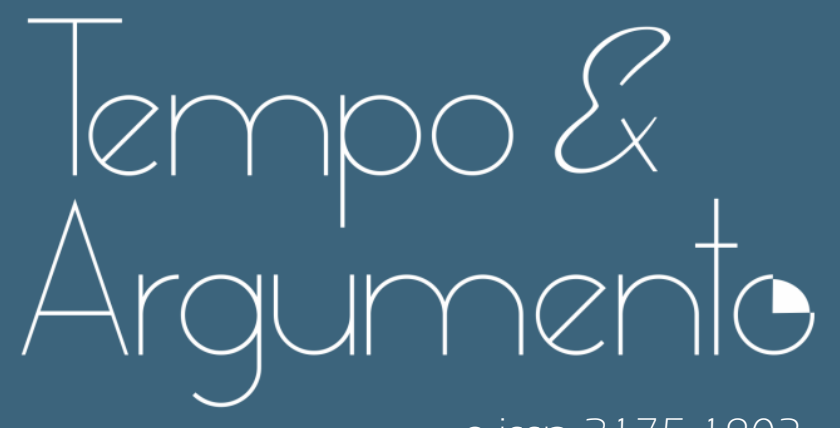

e-issn 2175-1803

Nosotras contamos. Notas en torno a construir genealogía feminista en el campo de la historieta y el humor gráfico (Argentina, 1933 - 2019)

Mariela Alejandra Acevedo

Doctora en Ciencias Sociales por la Universidad de Buenos Aires (UBA).

Investigadora del Grupo de Trabajo de Estudios de Género y Feminismos del

Instituto de Estudios de América Latina y el Caribe (IEALC-UBA).

Buenos Aires - ARGENTINA

authoraid.info/en/mentoring/contact/23948/

acevedo.mariela7@gmail.com

(1)

orcid.org/0000-0003-1628-8048

Para citar este articulo:

ACEVEDO, Mariela. Nosotras contamos. Notas en torno a construir genealogía feminista en el campo de la historieta y el humor gráfico (Argentina, 1933 - 2019).

Tempo e Argumento, Florianópolis, v. 12, n. 31, e0 106, set./dez. 2020.

doi) http://dx.doi.org/10.5965/2175180312312020e0106

Recebido: $15 / 04 / 2020$

Aprovado: 30/06/2020 


\title{
Nosotras contamos. Notas en torno a construir genealogía feminista en el campo de la historieta y el humor gráfico (Argentina, 1933 - 2019)
}

\begin{abstract}
Resumen
El artículo presenta la propuesta de "Nosotras contamos. Un recorrido por la obra de autoras de historietas y humor gráfico de ayer y hoy" una iniciativa de construcción de genealogía feminista en el campo de las viñetas humorísticas y artes secuenciales gráficas llevado adelante por la agrupación "Feminismo Gráfico" (Buenos Aires, 2019). El proyecto inicial se enmarca en abordajes de ginocrítica desde el que se propone redescubrir un arte hecho por mujeres (Showalter, 1981) y la genealogía feminista como metodología de investigación (Restrepo, A., 2016). Los resultados se plasmaron en un sitio web, una muestra itinerante y un catálogo que presentó un recorrido por la obra de más de ochenta autoras entre 1930 y la actualidad e implicó un proceso de investigación en hemerotecas, colecciones y archivos. La propuesta nos llevó a cuestionar la categoría "mujer" y a utilizar "autorías" como una categoría que fuera abarcativa no solo de feminidades sino también de identidades disidentes o transfronterizas que producen en el campo de las historietas y las viñetas de humor. Esto permitió reconstruir un mapa que vincula las luchas emancipatorias de mujeres, lesbianas, travestis/trans y personas no binarias con la plasmación de un registro gráfico en revistas de circulación popular. Parte de este proceso es recopilado en el sitio www.feminismografico.com.
\end{abstract}

Palabras clave: Historieta. Genealogía Feminista. Autorías.

\section{Nosotras contamos. Notes about build feminist genealogy on comic strips and graphic humor (Argentina, 1933 - 2019)}

\begin{abstract}
This paper presents the proposal of "Nosotras contamos. Un recorrido por la obra de autoras de historieta y humor gráfico de ayer y hoy" an initiative to build feminist genealogy in the field of humorous cartoons and graphic sequential arts. The initial project is framed in gynocritical approaches from which it is proposed to rediscover an art made by women (Showalter, 1981) and feminist genealogy as a research methodology (Restrepo, A., 2016). The results were reflected in a website, a traveling exhibition and a catalog that presented a tour of the work of more than eighty female authors between 1930 and today and involved a process of research in periodicals, collections and archives. The proposal led us to question the category "woman" and to use "authorship" as a category that contains feminities that produce in the field of comics and cartoons. This allowed us to reconstruct a map that links the emancipatory struggles of women, lesbians, transvestites / transgender people and non-binary people with the creation of a graphic document in popular circulation magazines. Part of this process is compiled on the website www.feminismografico.com.
\end{abstract}

Keywords: Comic. Feminist Genealogy. Authorship. 
Nosotras contamos. Notas en torno a construir genealogía feminista en el campo de la historieta y el humor gráfico (Argentina, 1933 - 2019)

Mariela Alejandra Acevedo

Construir genealogía feminista en las viñetas

"Este espacio es un nodo: queremos ser red y contagiar ganas de participar, de discutir y generar voces audibles, múltiples y diversas

que colaboren en el intento de construir conocimiento colectivo y politizado."

(Manifiesto de Feminismo Gráfico)

En Argentina, la historia sobre la participación progresiva de las autoras de historietas y humor gráfico está en construcción y presenta huecos, ausencias, signos de interrogación en donde debería haber nombres, fechas, trayectorias. Aunque durante muchos años las producciones de algunas (pocas) autoras fueron publicadas en revistas y ediciones de antologías la pregunta por las autoras o por su presencia minoritaria en las redacciones y staff de revistas comienza a emerger en los estudios a fines de los años ochenta en forma de artículos de rescate, de rastreos de los trazos de quienes dibujaban o escribían con ánimo de hacer reír o de satirizar, polemizar contra el sentido común instalado o contar historias dibujadas. ${ }^{1}$

A partir de la década del 2000 comienzan a emerger distintas aproximaciones que se preguntaron o hicieron visible el carácter excepcional con el que esporádicamente alguna autora era incluida en lo que Claudia Ferman (1994) - en referencia a la revista de historietas Fierro- había llamado un "bunker masculino". Generalmente, la respuesta de editores frente a la pregunta por las autoras constataban lo evidente (el mero reconocimiento de su ausencia), en algún caso nombraban las pocas autoras que existían o decían conocer o, el mejor de los casos, en concedían una apertura excepcional y limitada donde las

\footnotetext{
${ }^{1}$ El artículo de Silvia Itkin (1988) en Feminaria es una de las primeras aproximaciones al humor de las autoras en las publicaciones, Un interés desde la perspectiva de género en el medio se puede rastrear en el trabajo de Claudia Ferman (1994) sobre la obra de Patricia Breccia. Centrada en la producción humorística, Paulina Juszko (2000) realiza un trabajo más extenso y que abarca no solo a dibujantes sino también a quienes se desempeñaban en la radio, la tv y el teatro en El humor de las argentinas. El artículo de Ana von Rebeur (sin fecha) presenta una perspectiva desde el trabajo de una autora que escribe, dibuja y hace humor.
} 
Nosotras contamos. Notas en torno a construir genealogía feminista en el campo de la historieta y el humor gráfico (Argentina, 1933 - 2019)

Mariela Alejandra Acevedo

mujeres eran convocadas a participar por única vez en "un especial de chicas"2. Ese espacio, habitualmente reconocido como "la cuestión de la mujer en la historieta" no pasaba de dar cuenta que había alguna haciendo "algo" y que era inexplicable el motivo de que no hubiera más. Así, por ejemplo, al tiempo que se reconocía que no se publicaban autoras, se implementaban distintas "compensaciones" de carácter simbólico o justificaciones como señalar que presencia femenina abundaba (en los personajes creados por autores).

Así, iniciando la segunda década del siglo XXI, Lautaro Ortiz, jefe de redacción de revista Fierro, ${ }^{3}$ en una columna del diario Página 12 titulada "Cuando las mujeres reivindican su lugar" (2011) reconocía la ausencia de autoras y sostenía provocativamente que la falta de participación era compensada por las representaciones hechas por los autores. Escribía Ortiz:

No es casual que la revista Fierro haya elegido a esas mujeres enfurecidas, sexualmente rabiosas, de armas tomar, como tapa para la edición 52, que sale mañana junto a este diario. Si se tiene en cuenta el papel de la mujer en la historieta argentina se justificaría el gesto de bronca de esas chicas - magistralmente creadas por Diego Parés-, y hasta se podría suponer que este

\footnotetext{
Esta estrategia fue rastreada en revistas de historietas desde los años setenta (por ejemplo, revista TOTEM-Extra 2-Especial Mujeres en 1978 que dedica un número completo y explican en su editorial porque no van a volver a hacerlo: "En TOTEM la mujer siempre ha encontrado las puertas abiertas [...] Que quede bien claro además que si luego hemos limitado la publicación de colaboraciones femeninas nunca ha sido por considerarlas de inferior calidad, sino justamente por el motivo contrario: por considerarlas demasiado avanzadas e innovadoras." En EDITORIAL, 1978, p. 3). Se trata de una reunión de materiales de autoras francesas de la revista feminista Ah! Nana que había sido clausurada por el estado francés y de una selección de autoras españolas. La ficha del número se puede acceder en https://www.tebeosfera.com/numeros/totem 1978 nueva frontera -extra-_2.html). En Argentina, Revista Fierro en los ochenta dedicó dos suplementos en la sección para autoras/es noveles (Óxido). En el primer caso "Minas de Fierro" incluyó a tres autoras que ya publicaban profesionalmente (Patricia Breccia, María Alcobre y Maitena). Un segundo Especial "Nuevas Minas de Fierro", publicó ocho historietas de autoras no profesionales. (Acevedo, 2018) Revista Fierro en su segunda época editó el Suplemento Flores bajo la coordinación de Alejandra Lunik (Fierro 69) (Acevedo, 2016).

${ }^{3}$ La revista Fierro fue una de las más importantes revistas de antologías de historietas de salida mensual en Argentina. Tuvo una primera época en los años ochenta (1984-1992) con Ediciones de La Urraca, bajo la dirección de Andrés Cascioli y con diferentes jefes de redacción (Juan Sasturain, hasta el número 47, reemplazado por Marcelo Figueras,y entre el 60 y el cierre en el número 100, Pablo De Santis). La segunda época inicia en octubre de 2006 (Ediciones La Página) con Juan Sasturain en la dirección y Lautaro Ortiz durante todos los números mensuales hasta su cierre en la edición 125 (2017). Una tercera etapa de ocho volúmenes y de salida trimestral circuló entre 2017 y 2019 bajo la dirección de Lautaro Ortiz. Mi trabajo de tesis doctoral «Sextualidades gráficas. Sexuación del lenguaje y expresiones de la diferencia sexual en revista Fierro (1984-1992 y 2006-2015)» con dirección de Facundo Saxe se centró en las las dos primeras etapas y analizó las representaciones sociosexuales y la participación de las autoras y autores en la publicación (Acevedo, 2019a).
} 
Nosotras contamos. Notas en torno a construir genealogía feminista en el campo de la historieta y el humor gráfico (Argentina, 1933 - 2019)

Mariela Alejandra Acevedo

número trata de aplacar los ánimos. Pero no es así, la Fierro de este mes no viene con lo femenino en la costura, pero sí en el contenido. Para ser más claro: la única mujer que revela el sumario es la investigadora Laura Vázquez, quien precisamente se encarga de tirar la primera piedra en su columna "Ojo al cuadrito".(Ortiz, 2011).

En el "Ojo al cuadrito", columna crítica a la que hace referencia Ortiz, Vazquez (2011) publicaba "Channel n\#5" donde sostenía que las autoras debían llegar por mérito propio y que no había que crear espacios solo de autoras. Afirmaba que aunque no hubiera habido tantas autoras, el crecimiento había sido continuo desde los años noventa, y aseguraba además que había mayor paridad en los espacios de formación. (VAZQUEZ, 2011). Las autoras constituían - según su visión - un "ejército de individualidades" que daría frutos en diez o quince años, en la medida que las autoras integraran espacios mixtos y no participaran en "espacios exclusivos de mujeres." 4 También afirmaba, que a diferencia de lo que sucedía en los ochenta, sería "una antigüedad" publicar un suplemento especial de autoras. (VAZQUEZ, 2011). Sin embargo, un año y medio después, y como otra forma de compensación, Fierro contradecía a su columnista al reincidir en el "anacronismo" de agrupar autoras para publicarlas por única vez en el suplemento especial Flores. ${ }^{5}$ Hay que distinguir entonces el espacio que se abre para "agrupar" mujeres (o ponerlas en la mesita o el anaquel de las chicas) de las formas de reunión y autogestión de autoras que producen juntas y se autopublican. Son dos estrategias de visibilidad diferentes que pueden ser complementarias pero que no deberían confundirse.

Podríamos vincular estas formas en las que las autoras, de manera reciente, se hicieron más visibles con el resurgimiento del activismo feminista. El crecimiento en la presencia de autoras en muestras colectivas y festivales,

\footnotetext{
${ }^{4}$ La referencia parecía hacer alusión a la salida de la revista Clítoris, publicación bajo mi dirección que no se presentaba como espacio exclusivo de mujeres sino como propuesta de historietas feministas y sexodisidentes. La revista Clítoris había sido premiada en diciembre de 2010 para la publicación de cuatro números y la alusión que sanciona la propuesta como inapropiada se publica en la columna de Vazquez en la edición 52 (febrero 2011). Los cuatro números de revista Clítoris (2011-2013) y las dos antologías (Hotel de las Ideas, 2014 y 2017) se encuentran en línea en www.revistaclitoris.blogspot.com.ar

El suplemento Flores salió en Fierro 69 (julio de 2012) y agrupaba las propuestas de autoras nacionales y extranjeras entre las que se encontraban Clara Lagos, Caro Chinaski, Sole Otero, Powerpaola, Ana Galvañ, Delius, Pum Pum, Sonia Pulido, Laura Varsky, Carla Berrocal, Cecilia "Gato" Fernández, Julieta Arroquy, Pupi Herrera y la propia Alejandra Lunik, coordinadora del espacio (Ver Acevedo, 2016).
} 
Nosotras contamos. Notas en torno a construir genealogía feminista en el campo de la historieta y el humor gráfico (Argentina, 1933 - 2019)

Mariela Alejandra Acevedo

comenzó a generar espacios de producción, edición y publicación en el que las autoras y editoras hicieron visibles relatos y experiencias y con ellas también un conjunto de demandas de mujeres cis y trans, lesbianas, travestis, transmasculinidades y personas no binarias. ${ }^{6}$

En 2019, en Ciudad de Buenos Aires, un grupo de autoras y editoras que integramos "Feminismo Gráfico" nos propusimos reunir materiales de autoras de historieta y humor gráfico publicados entre 1930 (primeras viñetas que encontramos con firma de autora) y 2019 en revistas, publicaciones autogestivas y sitios digitales para conformar la muestra y el catálogo ${ }^{7}$ "Nosotras contamos. Un recorrido por la obra de autoras de historietas y humor gráfico de ayer y hoy". (ACEVEDO, 2019b). La propuesta fue, entonces, reconstruir un panorama que reuniera la obra de humoristas e historietistas en un recorrido por distintas épocas registrando su progresiva inserción, en una posible e incompleta genealogía de autoras del medio. ${ }^{8}$

\footnotetext{
${ }^{6}$ La emergencia del Festival Tinta Queer (Guzmán, 2016), El festival iVamos las Pibas! (Valenzuela, 2018) y la antología Pibas (Guzmán, 2019) permiten delinear espacios emergentes que transformaron la escena local a partir de coordenadas feministas y sexodisidentes. Un panorama diacrónico sobre la participación de las autoras en Argentina en Acevedo (2018b) y en Páez, (2020); una aproximación regional (Argentina, Chile, Brasil y México) en Acevedo et al. (2018). Se incluyen referencias en lecturas ampliatorias al final de las referencias bibliográficas. Feminismo Gráfico fue primero una iniciativa de sitio web en el que reunir la producción académica feminista sobre cultura visual. La posibilidad de obtener financiamiento nos permitió llevar adelante el proyecto de muestra y catálogo inspirado en el libro y la muestra Presentes. Autoras de tebeos de tebeos de ayer y hoy que llevaron adelante Elisa McCausland y Carla Berrocal en el estado español (AECID, 2016). El trabajo de las colegas fue el puntapié para conformar el equipo integrado por Femimutancia (artista gráfica y autoeditor) y Daniela Ruggeri (auto editora y diseñadora gráfica) bajo mi dirección. También se integró al equipo Helena Oliva (organizadora de eventos) que gestionó cuestiones de logística y promoción de la muestra. Para el acceso al catálogo completo Acevedo, 2019b.

${ }^{8}$ Con respecto a muestras colectivas de historietas vinculadas a una cuestión de género podemos citar tres antecedentes recientes. Primero, la muestra "Minas" (2015) que se exhibió en la tercera edición del Festival Comicópolis y estuvo a cargo de Judith Gociol aunque no se trató de una muestra de autoras sino que reunió material humorístico alrededor del tema "mujeres" y presentó tiras y chistes realizados por autores y autoras (Ver la nota de Leticia Pogoriles, 2015 para Agencia Télam) El segundo, es la muestra del colectivo de autoras Chicks on comics (Buenos Aires, verano de 2017) que realizó una exhibición de su trayectoria y una feria abierta a la que invitó a decenas de autoras a participar. (Ver una reseña crítica en Turnes y Vazquez, 2017). Tercer antecedente, "A flor de piel" muestra curada por Laura Vazquez (2018 Centro Cultural Recoleta, Buenos Aires) que reunió el trabajo de treinta y seis artistas de distintas épocas a partir del tema "piel" (Ver la reseña de Laura Rosso, 2018 en Diario Página 12). A diferencia de estas propuestas, las coordenadas de nuestro trabajo no entiende "género" como sinónimo de "mujeres" sino que se posiciona desde una perspectiva feminista / transfeminista e interseccional.
} 
Nosotras contamos. Notas en torno a construir genealogía feminista en el campo de la historieta y el humor gráfico (Argentina, 1933 - 2019)

Mariela Alejandra Acevedo

Enmarcamos la propuesta en un momento de expansión del feminismo que revisa la historia, a la que mira para darle sentido al presente buscando raíces en el pasado ${ }^{9}$ y que puede entenderse retomando los conceptos de ginocrítica y de genealogía feminista.

Elaine Showalter acuña el término "ginocrítica" en 1979 para oponer a esta modalidad de abordaje lo que ella denomina "crítica feminista" y que Toril Moi (1988) describe como "crítica a las imágenes de la mujer". Según Showalter la etapa revisionista de crítica en la que se denuncian estereotipos sexistas y exclusiones misóginas del canon blanco, masculino y heterocentrado debía dar paso al estudio de la creatividad e imaginación de las mujeres. Para concretar sus objetivos, Showalter sostendrá que existe una "cultura femenina" como "forma de experiencia colectiva dentro del todo cultural, una experiencia que liga a las mujeres escritoras entre sí más allá de límites espaciales o temporales" (OLIVARES, 1997, p. 56). La “crítica a las imágenes de la mujer” y la ginocrítica son dos formas de abordaje tradicionales en los estudios (que aún están vigentes en los análisis) y ambas tienen sus límites. La propia concepción de dos corrientes contrapuestas, es poco productiva ya que ambas estrategias pueden ser complementarias, pero además deben ser integradas por una concepción que entienda a la producción visual y a la autorías (marcadas por la clase, el género, la etnia, la orientación sexual) como elementos que se sintetizan en la recepción y, así, se pregunte también por las lectoras (GOLUBOV, 2011). En este sentido, el concepto de genealogías es productivo para el abordaje de la obra de autoras desde un marco feminista. Siguiendo a Rosa María Rodríguez Magda (2004) la genealogía puede identificarse como "patriarcal”, "de mujeres” y/o "feminista”. La

\footnotetext{
${ }^{9}$ Larrondo y Ponce (2019, p. 22) entienden que los movimientos feministas juveniles en la región han motorizado las demandas al tiempo que señalan la masificación a partir de 2015: "En los últimos cinco años, las principales ciudades de América Latina fueron escenario de grandes movilizaciones cuyas demandas no pueden ser soslayadas" y mencionan el surgimiento del movimiento \#NiUnaMenos en Argentina - dirigido en contra de los femicidios y la violencia hacia las mujeres-, como un emergente del que se hicieron eco colectivas y distintas organizaciones: "[...] En nuestra región, al movimiento feminista y a las demandas y reivindicaciones de género -en numerosos colectivos - se suman aquellas de clase y las demandas étnicas que han estado presentes históricamente." Este movimiento heterogéneo de mujeres, lesbianas, travestis y trans que demandan transformaciones culturales a la sociedad (erradicación de las violencias bajo la consigna "Vivas nos queremos" o "Ya no nos callamos más") y políticas públicas a los Estados (despenalización y legalización de la interrupción voluntaria del embarazo y acceso a la educación y la salud pública, entre otras) se articula con desarrollos teóricos y despliegues analíticos de la crítica feminista académica.
} 
autora, retoma el desarrollo de Michel Foucault quien desliga la genealogía de sus usos basados en el parentesco para utilizarla como método de indagación de las condiciones sociohistóricas que permiten la emergencia de discursos en redes de poder / saber. Rodríguez Magda (2009) retoma este concepto y lo piensa desde coordenadas feministas en donde las genealogías de mujeres y feministas se complementan, resisten y disputan sentido a las genealogías patriarcales.

Así, a partir de indagar en las condiciones de producción, circulación y recepción podemos retomar el concepto de ginocrítica de Elaine Showalter y complementarlo con el de construcción genealógica como búsqueda no de una historia-relato sino como el de una historia-problema en donde no solo es necesario reponer los nombres borrados y las trayectorias invisibilizadas sino indagar en las condiciones que hicieron posible eso y su transformación (RESTREPO, 2016). La propuesta ético-estética es la de recuperar las voces y experiencias de las mujeres cis y trans, lesbianas, travestis y personas no binarias que dejaron huellas en el recorrido.

Entre 2018 y los primeros meses de 2019 este trabajo implicó la búsqueda en archivos y hemerotecas, la construcción de un listado tentativo que para el mes de octubre de ese año tomó la forma de una muestra y un catálogo (Figura 01) que ofició de entrada a un universo plural, diverso, heterogéneo.

Figura 01 - Portada de libro catálogo: Con ilustración de Femimutancia, (seudónimo de la artista Julia Inés Mamone) y diseño editorial de Daniela Ruggeri

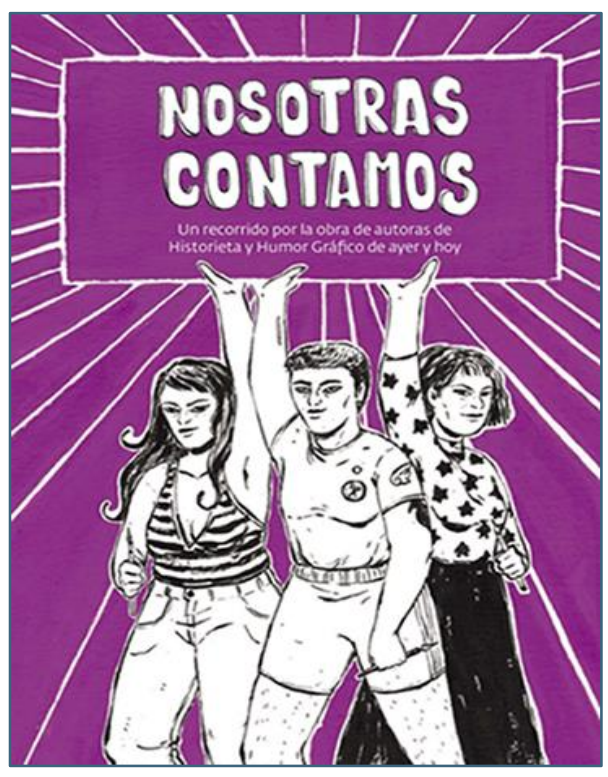

Fuente: (MAMONE, 2019). Portada, de Nosotras contamos. Acevedo, M (2019b) 
Nosotras contamos. Notas en torno a construir genealogía feminista en el campo de la historieta y el humor gráfico (Argentina, 1933 - 2019)

Mariela Alejandra Acevedo

Se trató de una propuesta gráfico-política que reunió una página por autora, una breve nota biográfica en torno a lo que se pudo reconstruir como trayectoria, una periodización que dio una pincelada breve de contexto de los trabajos y algunas notas en torno a los recorridos temáticos que además de la propuesta cronológica permitió plantearnos cuestiones en torno a los intereses que abordaron y abordan las creadoras de humor gráfico e historietas. La muestra reunió páginas de más de ochenta autoras del medio que publicaron en Argentina desde las primeras décadas del siglo XX hasta la actualidad y marcó un camino en forma de viñetas que puede pensarse como un recorrido histórico por un lado y diferentes entradas que reponen cuestiones en torno a corporalidades, espacios, roles, deseos, vínculos y militancias: marcas del paso de la historia donde las representaciones de feminidades y su vinculación con la esfera pública y privada se hacen palpables. ${ }^{10}$

La propuesta nos llevó a tomar decisiones y también a plantearnos algunos nudos problemáticos que nos parece interesante exponer: por qué reunir la obra humorística y no humorística de las autoras, cómo periodizar la obra a lo largo de siete décadas, por qué autora no es sinónimo de "mujer" y de qué forma cuestionar la construcción de un canon en el campo de la historieta y el humor gráfico para contribuir en la visibilización de una cultura feminista.

\section{Decisión de reunir la obra humorística y la vertiente "seria" de los trazos gráficos}

¿Por qué reunir a autoras de humor gráfico y de historietas? Seguramente habrá objeciones ante esta decisión. La mayoría de los estudios sobre el campo del humor en general y del humor gráfico en particular, con la intención de estudiar los mecanismos por los que produce sentido humorístico, separan la obra de cartoon o tira humorística de aquella que se reconoce como historieta de aventura, por lo general más extensa y que no tiene intención de comicidad.

\footnotetext{
10 La muestra exhibió ochenta y dos gráficas a color, en un tamaño de 50x70cm de las obras seleccionadas y se acompañó de un catálogo en formato físico y digital, con el registro completo de la selección de trabajos y unas breves líneas biográficas y de contextualización de las obras. La difusión se realizó a través de la página web www.feminismografico.com y redes sociales. El sitio web además de la muestra, incluye reseñas y se presenta como un laboratorio de ideas y difusión de trabajos de creadoras e investigadoras feministas. El proyecto se llevó adelante con un financiamiento del Fondo Metropolitano de la Cultura, las Artes y las Ciencias del Gobierno de la Ciudad de Buenos Aires (2018).
} 
Nosotras contamos. Notas en torno a construir genealogía feminista en el campo de la historieta y el humor gráfico (Argentina, 1933 - 2019)

Mariela Alejandra Acevedo

Esta separación tiene sentido aunque también recorta trayectorias, ya que hay autoras como Maitena o Patricia Breccia que desarrollaron su trabajo como humoristas e historietistas, dándole más relevancia a una u otra faceta. De manera que solo abordar su trabajo humorístico deja en la sombra parte de su producción.

Cuando nos decidimos a armar nuestra genealogía nos enfrentamos a varios problemas y este fue uno de ellos ya que la mayoría de los estudios se interesan por las autoras que se dedican o dedicaron al humor, por sobre aquellas que lo hicieron a la narración gráfica más extensa. El problema se pone en evidencia cuando delimitamos el alcance y los criterios para integrar la muestra/catálogo: Dejar afuera a las humoristas para concentrarnos solo en las que publicaron historieta no humorística nos impedía incluir a las pioneras y sus colaboraciones en revistas como Sintonía en los años treinta o Tía Vicenta a mediados de los cuarenta. Nos referimos a los primeros trabajos más cercanos a la ilustración de carácter cómico como aquellos que publicaron Niní Marshall bajo el seudónimo de Mitzi (Figura 02) o Blanca Cotta como Cerebela.

Figura 02 - Las viñetas firmadas por Mitzi (más conocida por el seudónimo de actriz cómica de radioteatro, "Nini Marshall") ilustraban su mordaz columna sobre espectáculos en la Revista Sintonía año (1933). Allí, la dibujante y escritora criticaba a colegas, opinaba sobre la participación de las mujeres en los medios de comunicación y mostraba su versatilidad para hacer humor en distintos soportes.

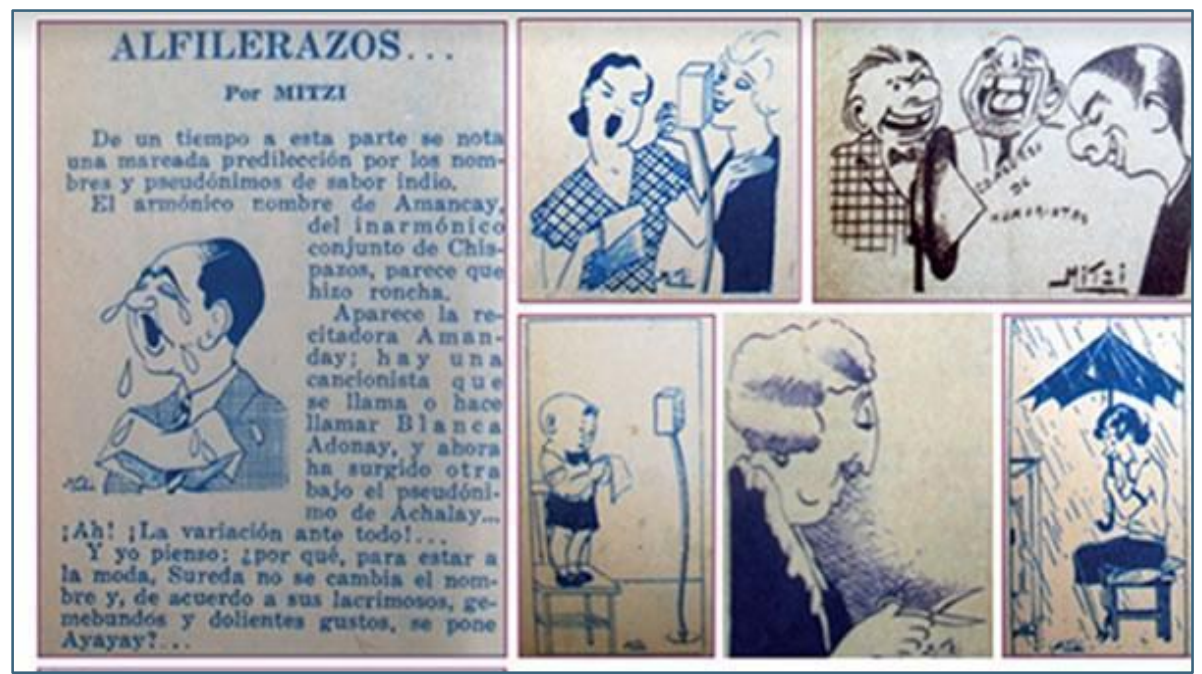

Selección de ilustraciones de Mitzi. Fuente: Nosotras contamos (Acevedo, 2019b p. 14)

Reunir solo el trabajo de autoras humoristas como hace Silvia Itkin (1988) o más cerca en el tiempo, Mara Burkart (2018) o poner bajo la lupa distintas 
expresiones como el humor literario, televisivo o gráfico como hace Paulina Juszko (2000) es una posibilidad que valoramos pero que dejaba afuera el trabajo de las autoras en revistas de historieta más clásica. Generalmente los trabajos de estas autoras (Martha Barnes, Idelba Dapueto, Alicia Castro Nistal) son menos conocidos y escasamente valorados. Como las historietistas fueron menos estudiadas, tuvimos que apelar a colegas coleccionistas, a archivos y hemerotecas, para reconstruir trayectorias de quienes iniciaron sus carreras en la escena local entre las décadas del treinta y sesenta. Aunque de forma bastante decepcionante la mayoría de las veces los datos que acompañaban las pocas líneas biográficas se limitaban a señalar la vinculación sentimental o familiar con algún autor.

En nuestra propuesta, separamos a las humoristas gráficas de las productoras de humor en general y las ubicamos en diálogo con el campo autoral de otra forma de producción gráfica que en muchas ocasiones no exploran el humor: las historietas de aventura. Si tenemos que justificar esta decisión podríamos señalar que esta dicotomía viñeta de humor/ historieta seria suele tener zonas de contacto en las que los elementos de una y otra se solapan. Tal como señala Roberto von Sprecher (2009, p. 89-91) al relevar los rasgos que distinguen la historieta humorística de la historieta de aventuras (también denominada "realista") esta última se distingue por "contraste con la humorística". Pero advierte que "hay que tener en cuenta la relatividad de los rasgos característicos de cada una de ellas. Entre ambas hay amplias zonas grises, o fronterizas, en las cuales resulta difícil determinar la pertenencia a uno u otro tipo." (VON SPRECHER, 2009, p.89). Entre los rasgos que debemos observar en la historieta realista, en comparación con la humorística, enumera: un mayor grado de iconicidad frente a rasgos caricaturescos, búsqueda de mayor verosimilitud en el tratamiento de temas y mayor complejidad en las técnicas narrativas de montaje (planos, ángulos, etc.), mayor extensión y uso de la intriga o suspenso narrativo. Estas diferencias también son tenidas en cuenta por Federico Reggiani (2012) quien analiza a qué estilo de dibujo se aplica el término "realista". Reggiani aborda los antecedentes históricos de ese estilo y la posibilidad de que la historieta pueda constituir un realismo y entiende que este término no se ajusta al debate sobre realismo en el arte, sino a una 
autonominación que hacen quienes producen (y leen) historietas y que se refiere a la oposición entre historietas humorísticas y lo que, con significativa ambigüedad, se conoce como historieta "seria" o "de aventuras". Y apunta:

La terminología es por lo menos curiosa. La historieta humorística tiene objetivos más o menos evidentes (hacer reír, causar en algún sentido gracia). Sin embargo, es por lo menos extraño incorporar a la categoría de "historieta realista", relatos protagonizados por guerreros sumerios, sujetos inmortales, sobrevivientes de un holocausto nuclear o agentes secretos. La noción de "historieta seria”, por su parte, parecería condenar a las historietas que caen bajo esta categoría a un mundo de solemnidad un tanto alarmante. (Reggiani, 2012, p.130)

Estas ambigüedades o problemas de nominación nos alertan y nos llevan a pensar que esta división, entre humorismo/aventura primero, no sería productiva para nuestros fines, el de construir una genealogía; y segundo, es otro de los binarismos que se instituyen en la historieta que nos interesa desorganizar (así como la jerarquía entre la palabra portadora de la ley y la imagen con estatuto de verdad $)^{11}$. Aunque para ciertos casos de estudio la diferencia que existiría entre una historieta humorística reconocible por sus rasgos retóricos, temáticos y enunciativos (STEIMBERG, 1993) y distinguible de aquella denominada "seria", "realista" o "de aventura” pueda ser necesaria, la reunión bajo la muestra y el catálogo del lenguaje gráfico que explora la viñeta y la página desde distintos registros que incluyen el humor y la aventura puede entenderse también como la apuesta por desordenar esos rígidos binarios y mostrar las fronteras que entre una y otra se tienden como zonas de pasaje o de indistinción que ponen en cuestión estos registros como bloques separables en unidades discretas.

Una segunda razón de carácter pragmático que puede esgrimirse, es que al recorrer el catálogo de la muestra Nosotras contamos... podemos notar que las revistas que en los años setenta producen una renovación en el mercado de publicaciones incluían tanto historietas como tiras gráficas y comienzan a ser el terreno en el que incursionan algunas de las autoras que desarrollaron ambos registros. Hasta entonces las autoras de historieta "seria” o realista publicaban

\footnotetext{
"La discusión sobre los binarismos en la historieta excede este paper y la extensión que puedo darle en una nota al pie. Trabajé en torno a esta cuestión en la tesis de doctorado (Acevedo, 2019a) en donde entre otras cuestiones se rastrearon las metáforas entre el orden escrito (la ley) y el orden dibujado (la verdad) como formas que reponen la tensión entre lo masculino y lo femenino.
} 
Nosotras contamos. Notas en torno a construir genealogía feminista en el campo de la historieta y el humor gráfico (Argentina, 1933 - 2019)

Mariela Alejandra Acevedo

mayormente en revistas de la Editorial Columba, se trataba de autoras que no solo incursionaron en historias del "corazón" sino que exploraron universos corsarios, del western o del mundo del espionaje. Revistas como Satiricón (en los años setenta) o más tarde las de Ediciones de la Urraca (durante los años ochenta) con Humor, SexHumor, SuperHumor y Fierro abrieron posibilidades a las participaciones de Patricia Breccia, María Alcobre, Marta Vicente, Petisui y Maitena, autoras que -en algunos casos- transitaron entre el registro humorístico y el de las narrativas gráficas "serias". Otras autoras, encontraron espacio por esos años, en publicaciones femeninas como Vosotras o ligadas a la actualidad como Siete Días, tal el caso de Nelly Hoijman que publicará pocos años pero que en su casa de Palermo atesora cientos de páginas de catarsis dibujada; o las denuncias feministas que comienza a dibujar Diana Raznovich quien destina su talento de humorista a dibujar para Lugar de Mujer, el espacio que en los ochenta sirvió de refugio para quienes necesitaban orientación sobre lo que años más tarde se tipificaría como violencia machista. La página que expusimos de Diana Raznovich fue parte del Manual de Instrucciones para Mujeres Golpeadas (Lugar de Mujer, 1989) realizado con los textos de Lucrecia Oller. (Figuras 03 y 04 )

Figura 03 - Ilustración de portada del Manual de Instrucciones para mujeres Golpeadas (Lugar de Mujer, Buenos Aires, 1989) Diana Raznovich y Lucrecia Oller.

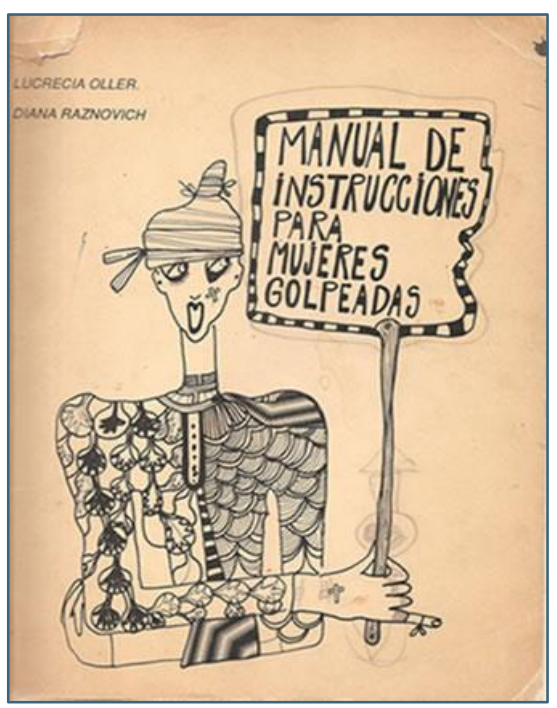

Figura 04 - Interior de Manual por Diana Raznovich (1989). Incluida en la muestra y catálogo "Nosotras contamos..." (Buenos Aires, 2019)

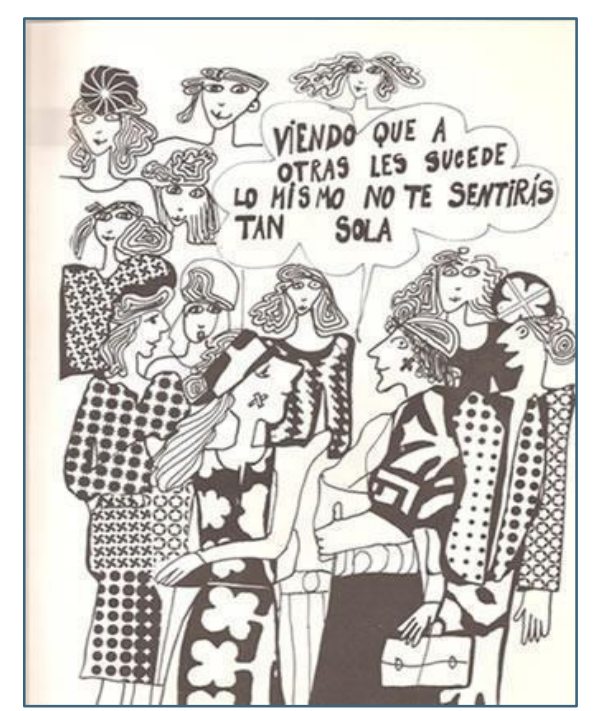

Fuente: RAZNOVICH, Diana (junto a OLLER, Lucrecia, 1989) en Nosotras contamos (Acevedo, 2019b p. 30) 
Nosotras contamos. Notas en torno a construir genealogía feminista en el campo de la historieta y el humor gráfico (Argentina, 1933 - 2019)

Mariela Alejandra Acevedo

Nos gustaría detenernos en este material porque se trata de una propuesta gráfica que circuló hace tres décadas en Buenos Aires y que remite a las demandas feministas de visibilizar las agresiones contra mujeres en manos de sus parejas y exparejas como expresiones de una violencia estructural de carácter patriarcal. En el contexto de la muestra y a treinta años de aquella primera edición rescatamos el Manual y lo volvimos a poner en circulación con una entrevista pública entre la socióloga María Alicia Gutiérrez y la artista Diana Raznovich. Las viñetas de humor feminista, lejos de la definición que Reggiani formula más arriba, no pretenden ser graciosas ni hacer reír, por lo que queremos volver a subrayar la necesidad de repensar estas divisiones y definiciones de humorismo/ historieta seria.

Otro ejemplo de humor feminista menos conocido es el de Sylvia Bruno, quien publicara en la revista Persona en los años setenta ${ }^{12}$. No pudimos reconstruir casi nada de su trayectoria: solo las páginas de "Feminita" (Figura 05) su personaje dibujado que denuncia la opresión y la injusticia de ser mujer en un mundo hecho a la medida de los hombres es lo que nos queda. Incluirla en una genealogía de autoras de historieta es una forma muy modesta de reconocer su trabajo.

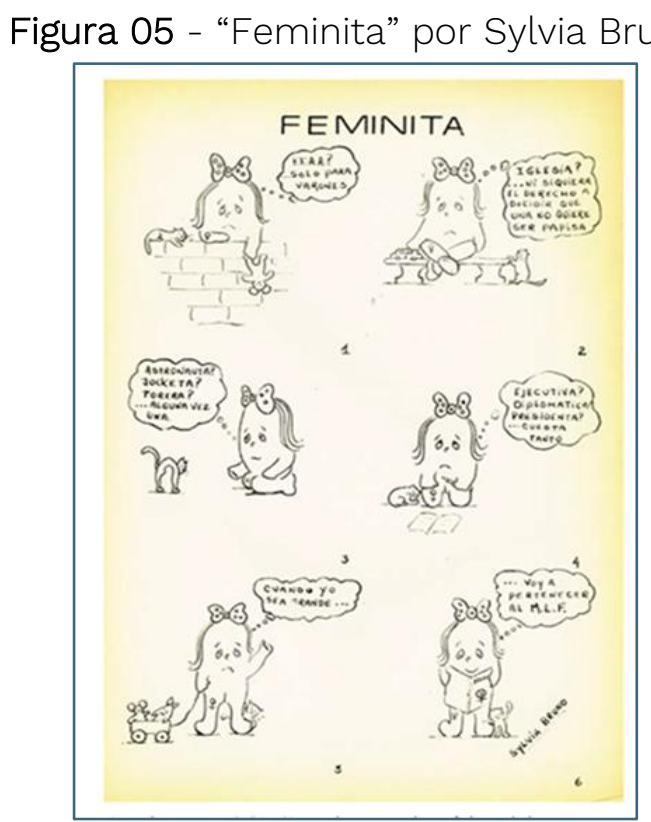

Fuente: BRUNO, Sylvia (1974) en Nosotras contamos (Acevedo, 2019b p. 28)

\footnotetext{
12 La recuperación de los números de revista Persona, en los que publicó Sylvia Bruno se encuentran digitalizados en el sitio América Lee de CEDINCl de donde obtuvimos las reproducciones para la muestra. La revista Persona circuló en Buenos Aires bajo la dirección de María Elena Oddone entre mediados de los setenta y principios de los años ochenta.
} 


\section{La periodización, la recuperación de trayectorias y otros obstáculos en la construcción de nuestra historia}

La decisión de reunir autoras de historieta y humor gráfico nos permitió hacer visible su participación desde las primeras décadas del siglo XX más vinculadas a la ilustración cómica y delinear como el espacio fue ocupado cada vez de forma más expansiva por quienes reclamaban la oportunidad de contar historias, documentar experiencias, ilustrar situaciones. La periodización que plasmamos muestra el progresivo incremento numérico de artistas dedicadas a la producción gráfica que pasa de unas decenas en un período de varias décadas (entre los treinta y principio del 2000) a una explosión incontenible en los últimos quince años (a partir de mediados de 2000 señalamos la irrupción de lo que denominamos "escena actual" y sabemos que muchas autoras por una cuestión espacial quedaron afuera). La periodización es una construcción problemática: establecer cortes, determinar experiencias comunes, señalar características marcadas por una determinada temporalidad es en gran medida arbitrario. Elegimos cuatro figuras - pioneras, okupas, fanzineras y feriantes- que sintetizan desde nuestro punto de vista transformaciones relevantes para la democratización de un espacio mayormente masculinizado: cambios que impulsaron innovaciones tecnológicas y de espacios de sociabilidad. Así, de las revistas como campo de inserción en las primeras décadas visualizamos la irrupción de las fotocopiadoras y de prácticas de autogestión como el principio de una expansión que construyó nuevos circuitos de producción y consumo y que dio paso a las ferias y eventos de presentación de libros así como a la emergencia de las pequeñas editoriales como espacios de profesionalización.

La agenda feminista se hace presente con distinta intensidad a lo largo de todo el recorrido, aun en autoras que tal vez no se reconocerían como feministas aunque sus temas aborden cuestiones vinculadas a las desigualdades de género, a la experiencia de transitar la calle con vergüenza o miedo, a problematizar la maternidad, a repensar la corporalidad y la sexualidad, a hacer visible la socialización desde la infancia. En algún sentido eso es subrayado por nuestra elección de qué mostrar y desde qué coordenadas leerlo pero también es una lectura que habilitan las páginas realizadas por las autoras que en ningún caso 
fueron previamente encargadas para una muestra feminista. La selección fue realizada sobre el material elaborado, que previamente había sido editado en distintas producciones, de diferentes sellos editoriales o propuestas colectivas.

\section{Identidad, género y experiencia}

Otro nudo problemático que nos llevó a tomar una decisión en torno a lo que una genealogía feminista debería recuperar fue la cuestión identitaria. La propuesta de Nosotras contamos...emerge en diálogo con el trabajo que el colectivo de autoras de cómic, bajo el sello de la Asociación de Autoras de Tebeos viene realizando en España (MCCAUSLAND; BERROCAL, 2016). La muestra y el catálogo de las colegas españolas que se puede encontrar libre en Internet ${ }^{13}$ actuó como una suerte de espejo en el cuál reflejarnos pero también una superficie de contraste con nuestro propio recorrido. Así, una discusión que nos dimos fue sobre el alcance de la categoría "mujer" y su vinculación con la de "autoras" y la necesidad de que esta última estuviera vinculada a las condiciones de producción y recepción de un discurso feminista no esencialista. De manera que, al momento de construir nuestra propia historia local decidimos también pensar la propuesta desde un espacio en el que las autorías feminizadas pueden reconocer y exceder la categoría "mujer" como sucede por ejemplo con Alyen, autore no binarie que publica en la revista lesbofeminista Baruyeras que posteriormente transitaría a una identidad masculina ${ }^{14}$. Esto nos presentó muchas dudas y miedos, ¿debíamos invitarlo? Alyen, hacía diez años había representado una marca importante a recuperar en la construcción de nuestra genealogía gráfico-feminista. Dejar afuera su trabajo era invisibilizar esa huella, pero por otro lado, a raíz de su tránsito e identidad actual, ¿era apropiado incluirlo en una muestra de autoras? Lo mejor fue preguntarle y arriesgarnos a que nos rechace. Su respuesta fue: "participar en una muestra de autoras no hace peligrar mi masculinidad" y con esa frase la bella estampa de sexo lésbico entre Mafalda y Libertad entró en nuestro catálogo para siempre (FIGURA 06). Ninguna duda

\footnotetext{
13 Una versión digital del catálogo de autoras españolas puede accederse en https://issuu.com/publicacionesaecid/docs/presentes._autoras de tebeo_de_ayer

${ }^{14}$ En 2018 incluí la viñeta de Alyen en un artículo que presenté en las jornadas CINIG (Acevedo, 2018b) y una asistente reconoció la gráfica y me puso en contacto con su autor.
} 
Nosotras contamos. Notas en torno a construir genealogía feminista en el campo de la historieta y el humor gráfico (Argentina, 1933 - 2019)

Mariela Alejandra Acevedo

sentimos en cambio al incluir las propuestas que narran los tránsitos o fugas de un género asignado al nacer hacia la autopercepción de mujeres o transfeminidades como lo plasmaron en sus trabajos Gaby Binder, autora de Chica trans (Figura 07) o Effý Mía en las viñetas de su trabajo "TRANSita rápido / TRANSita lento" (Figura 08).

Figura 06 - Alyen parte de una genealogía feminista que incluye a personas no binarias.

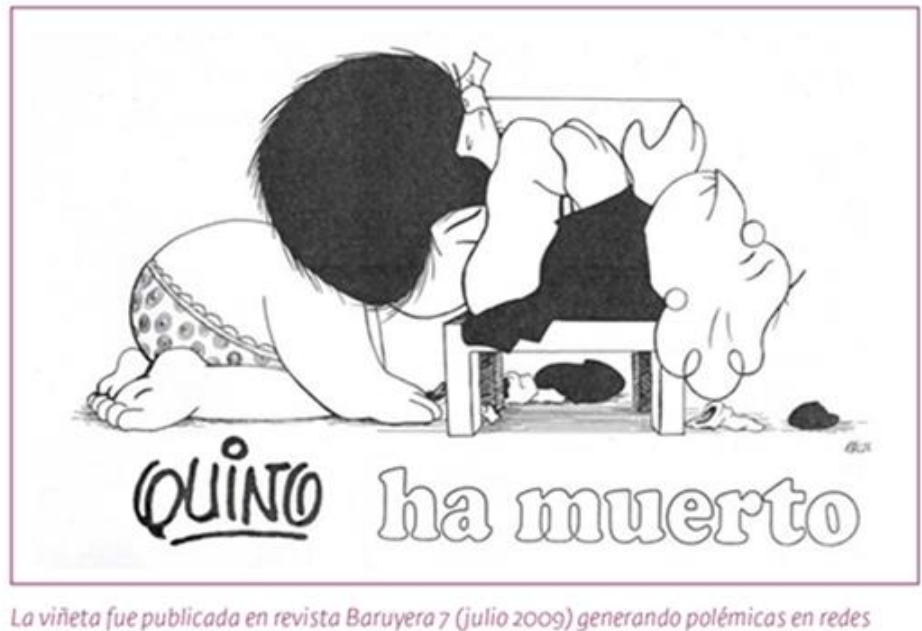
sociales hasta la actualidad.

Fuente: ALYEN (2009) en Nosotras contamos (Acevedo, 2019b p. 46)

Inscribir estas producciones en una genealogía de autoras, implica revisar la historia de nuestras luchas desde una perspectiva no esencialista. Tal como señala Matías Máximo en la introducción a las viñetas de Effy:

TRANSita muestra un cotidiano trans donde las cosas no están preparadas para vivir por fuera de una casilla de hombre o mujer. En ese territorio, que podemos leer como "comic de no ficción", la vemos a Effy saliendo de su casa, teniendo relaciones sexuales, yendo a una guardia de hospital o al trabajo. Situaciones que podrían ser rutina, pero que con la óptica de una sensibilidad particular hacen lupa en qué cuerpos tienen derechos y cuáles tienen que pagarlo caro.

[...] Las tiras de TRANSita fueron compartidas por primera vez en enero de 2012, año clave para Argentina en materia de derechos LGBTIQ+ por la sanción de la Ley de Identidad de Género. Por ello es que en algunas de ellas aparecen trastornos judiciales que hoy estarían fuera de la ley: por ejemplo, la demanda que le quiere iniciar al Estado por no otorgarle una rectificación acorde a su identidad, o el atajo que le niega un médico para conseguir 
hormonas (llenar una ficha como enferma de cáncer) para adquirirlas dentro de su cobertura social. [...] dibujar para desafiar a los géneros con "voz de pito", "vozarrón", "lampiño como una mina" o "peluda como un tipo". Esa voz, voz íntima y colectiva, está presente en estas historias, que guardan el retrato de una iniciación y dejan un eco de preguntas abiertas. (MÁXIMO, 2012, s/p)

En este recorrido algunas cuestiones que nos interesó recuperar fueron expresiones de testimonios gráficos vinculados a las luchas de las mujeres, lesbianas, travestis, trans y personas no binaries. Y eso significó en algunos casos suspender o expandir la categoría "mujer" para dar cabida a autorías que se autoperciben como no binarias, en tránsito o en fuga de las identidades asignadas al momento de nacer.

Figura 7 - Chica trans por Gaby Binder

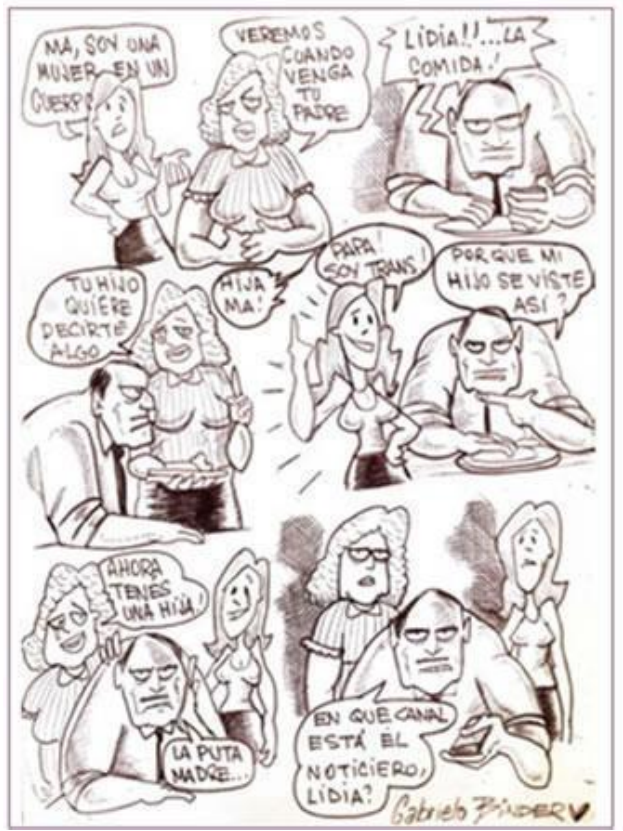

Fuente: BINDER (Facebook, 2014) en Nosotras contamos (Acevedo, 2019b p. 65)
Figura 8 - TRANSita por Effý Mía

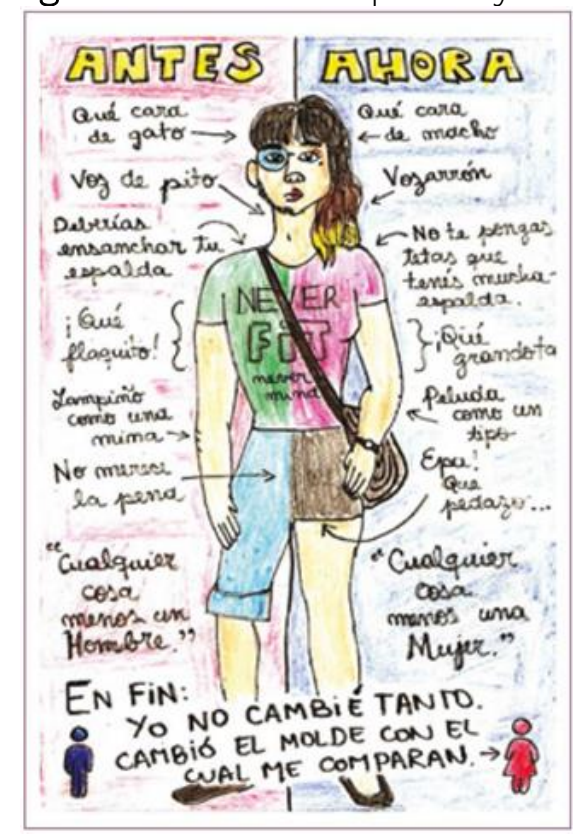

Fuente: EFFÝ MIA, fanzine autogestivo, 2012 en Nosotras contamos (Acevedo, 2019b p. 59)

También recuperar la historia de nuestras injusticias, esas que se hacen con formas violentas de disciplinamiento y que impulsan a las autoras a dejar plasmada historias como la de "Higui", sobreviviente de un intento de violación correctiva, en la que se defendió y quedó presa por asesinar a uno de sus agresores ${ }^{15}$ contada en una página por Cecilia Gato Fernández (Figura 09) para la

\footnotetext{
15 Para conocer pormenores de la historia de Higui ver la nota de Adriana Carrasco en Página 12 https://www.pagina12.com.ar/243430-se-viene-el-juicio-a-higui-acusada-por-defenderse
} 
Nosotras contamos. Notas en torno a construir genealogía feminista en el campo de la historieta y el humor gráfico (Argentina, 1933 - 2019)

Mariela Alejandra Acevedo

revista "Cuadernos de militancia lesbiana. ${ }^{16} \mathrm{O}$ el beso castigado de Marian Gómez y Rocío Girat (Figura 10) que se judicializó en una suerte de sanción ejemplar para que el matrimonio igualitario parezca apenas una hoja de papel que no modifica los actos de lesbo-odios institucionalizados. ${ }^{17}$ La historieta de Nacha Vollenweider fue publicada en Tortas y Bollos y recuperada en la muestra.

Figura 9 - Violencia contra lesbianas. La historia de Higui por Cecilia Gato

Fernández para Cuadernos de Militancia Lebiana.

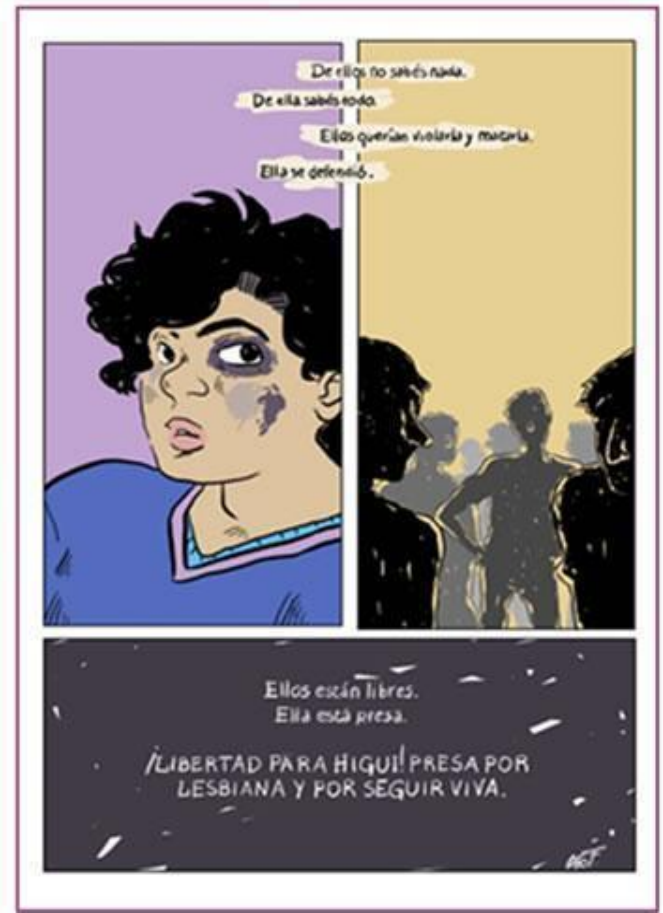

Fuente: Fernández, 2017 en Nosotras contamos (Acevedo, 2019b p. 49)
Figura 10 - Lesbofobia contra Rocío Girat y Marian Gómez en "Prohibido fumar" de Nacha Vollenweider.

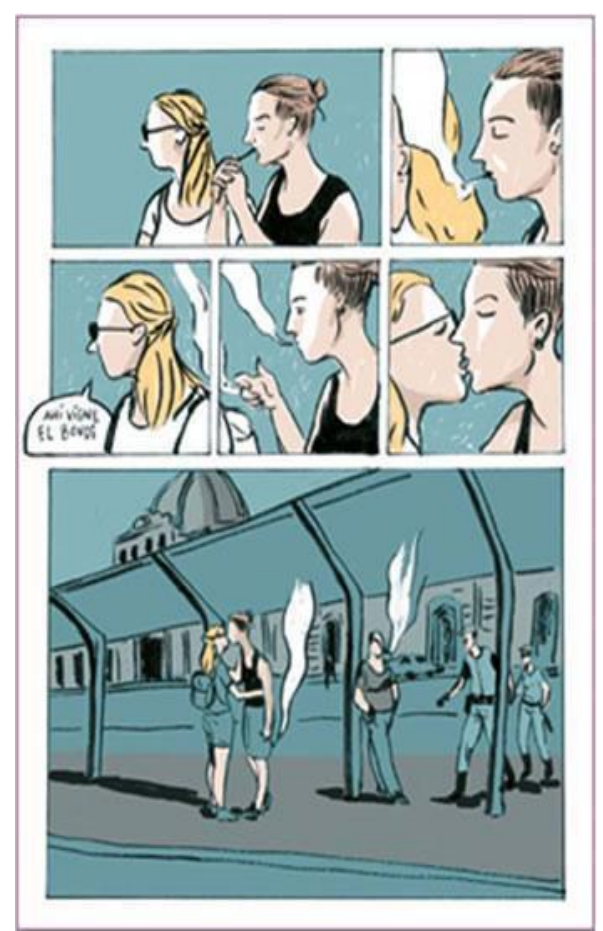

Fuente: Vollenweider, 2019 en Nosotras contamos (Acevedo, 2019b p. 57)

\section{Una reflexión sobre barreras, pisos pegajosos y techos de cristal}

La muestra reunió en las paredes de la Redacción Abierta de Latfem en Ciudad de Buenos Aires las páginas impresas de muchas décadas, en diálogos

\footnotetext{
16 Cuadernos de Militancia Lesbiana fueron publicados entre 2016 y 2017 por Adriana Carrasco quien retoma la senda de los Cuadernos de Existencia Lesbiana (de los años ochenta). Para una aproximación a la historia de esta primera publicación lesbofeminista ver la nota de Carrasco en Revista Anfibia http://revistaanfibia.com/cronica/cuadernos-existencia-lesbiana/

7 La historieta de Nacha Vollenweider narra el episodio de Mariana Gómez condenada a un año de prisión en 2019 por resistencia a la autoridad tras besar a su esposa Rocío Guirat en la vía pública. Para ampliar los detalles de lesbofobia en la acusación y durante el juicio ver la nota de Página 12 https://www.pagina12.com.ar/203159-un-ano-de-prision-por-el-beso-entremujeres-en-constitucion
} 
Nosotras contamos. Notas en torno a construir genealogía feminista en el campo de la historieta y el humor gráfico (Argentina, 1933 - 2019)

Mariela Alejandra Acevedo

cruzados, intergeneracionales, dando cuenta de que nosotras estábamos ahí en una historia de las publicaciones que muchas veces no nos mencionan. Las reflexiones que podemos hacer (y en las que indagamos en las entrevistas con tres generaciones de autoras representadas por Martha Barnes, Patricia Breccia y Sole Otero $)^{18}$ tienen que ver con el trabajo hecho por mujeres en espacios fuertemente masculinizados.

María Ruido (2004) señala en un ensayo sobre la situación de las trabajadoras de la cultura en el Estado español las consecuencias negativas de la masculinización de los espacios creativos en donde los circuitos son hegemonizados por productores y autores que dejan poco o nulo espacio a creadoras. El carácter excepcional de ingreso como autora se reitera en otras coordenadas y es (sigue siendo) un problema en la actualidad cuando vemos convocatorias donde evidentemente es necesario generar mecanismos como cupos, cuotas o políticas de ingreso con perspectiva de género. En otros campos creativos, también lo denunciaron por ejemplo, trabajadoras de la música quienes abogaban por espacios más democráticos en festivales y escenarios, con la resistencia de los colegas que sostienen falsas premisas de "meritocracia". ${ }^{19}$ Un ejemplo gráfico que nos parece interesante traer es la portada de Fierro \#10 realizada por Alejandra Lunik en agosto de 2007 (Figura 11). La disparidad entre la cantidad de autoras existentes en el campo y las muy excepcionales ocasiones en las que una autora accede a espacios de consagración como la portada de una publicación de antología apunta a una notoria falta de "justicia espacial"20.

\footnotetext{
18 Realizamos las entrevistas Julia Inés Mamone y yo en diciembre de 2018 con registro del equipo del programa Guión y Dibujo. Un registro de las notas se puede acceder en el canal de Feminismo Gráfico y se espera en el futuro avanzar hacia un documental. Se encuentra en línea en el canal de youtube de Feminismo Gráfico https://www.youtube.com/watch?v=g1M2bmrdolo

${ }^{19}$ La exigencia por espacios en escenarios y festivales musicales consiguió a fines de 2019 que el parlamento sancionara una ley que garantiza el 30 por ciento de presencia de mujeres (solistas y vocalistas de bandas) en los espectáculos públicos y privados. Ver

${ }^{20}$ El concepto desarrollado por el geógrafo Edward Soja combina el concepto de justicia social y espacialidad pensando en la distribución urbana, aquí nos hemos reapropiado de él para pensar la injusta distribución de espacios en términos de género de los espacios materiales y simbólicos.
} 
Nosotras contamos. Notas en torno a construir genealogía feminista en el campo de la historieta y el humor gráfico (Argentina, 1933 - 2019)

Mariela Alejandra Acevedo

Figura 11 - Portada de Alejandra Lunik. Única autora que firmó una portada en la revista Fierro en sus tres etapas de publicación (cien números entre 1984-1992/ ciento veinticinco números entre 2006-2017/ ocho volúmenes entre 2017-2019)

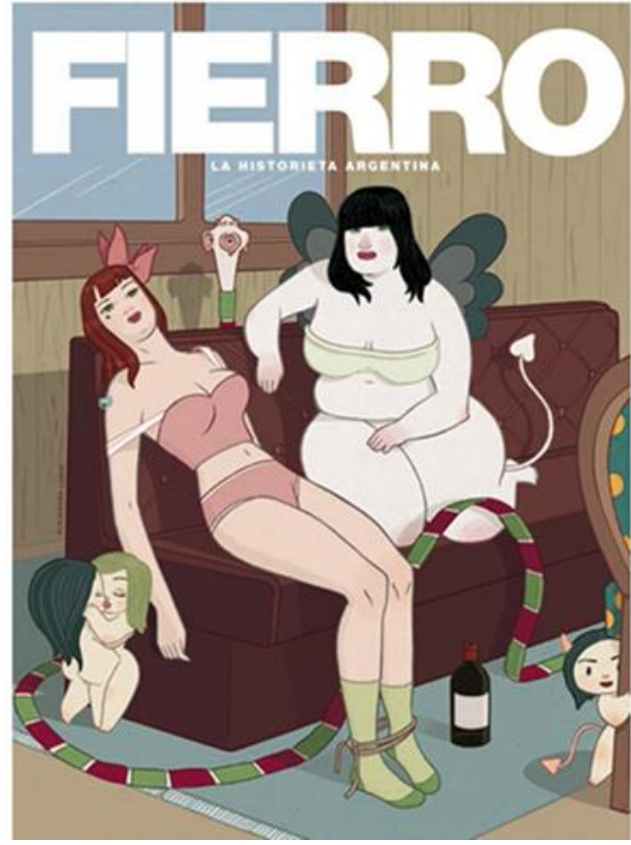

Fuente: LUNIK, 2007. En Nosotras contamos (Acevedo, 2019b p. 37)

En este sentido, podemos repensar la espacialidad y el género recorriendo el campo de la producción local y repensando los usos de "techo de cristal" que refiere a espacios de ascensión vertical como empresas para reconceptualizar las barreras o los distintos puntos de partida, "los pisos pegajosos". ${ }^{21}$ Se han popularizado conceptos como el de "manspreading" o uso excesivo del espacio que hacen algunos varones en el transporte público y que han sido documentados por activistas en las redes sociales.

\section{Para concluir: Hagamos el humor}

Para finalizar este breve recorrido, quisiéramos volver al tema del humor en la muestra y el catálogo de Nosotras contamos para destacar la importancia en las autoras de lo que denominamos "la escena actual" del uso de redes sociales y de la viñeta rápida para comunicar escenas de la experiencia militante en las calles. Una de las luchas que convocó autoras durante 2018 fue el debate

\footnotetext{
${ }^{21}$ Sobre "techos de cristal" y "pisos pegajosos" ver la entrada de Magali Brosio en Economía Femini(s)ta http://economiafeminita.com/de-techos-de-cristal-y-pisos-pegajosos/ Desarrollé el concepto de barreras que dificultan la entrada y permanencia al campo historietil en Acevedo 2011 y 2012.
} 
Nosotras contamos. Notas en torno a construir genealogía feminista en el campo de la historieta y el humor gráfico (Argentina, 1933 - 2019)

Mariela Alejandra Acevedo

parlamentario sobre el acceso a la Interrupción Voluntaria del Embarazo (IVE) impulsado por la Campaña por el Derecho al Aborto Seguro, Legal y Gratuito. En ese contexto, un conjunto de dibujantes se nuclearon en Línea Peluda, una colectiva inorgánica que emerge en un chat de Whatsapp para conformarse como espacio de producción con un objetivo:ponerle imágenes a los argumentos de acceso a la salud y la decisión de quienes tienen capacidad de gestar para exigir aborto legal. ${ }^{22}$

En la muestra recuperamos dos intervenciones que apelan a esta memoria de luchas y que circularon profusamente: Julieta Arroquy (Figura 12) con su cigüeña que en lugar de traer un bebé se embandera con el pañuelo verde característico de la Campaña Nacional por el Aborto Legal, Seguro y Gratuito; y la viñeta de Ro Ferrer que registra la visita de apoyo que integrantes de la Campaña realizaron a Chile (Figura 13) con motivo de apoyo a las movilizaciones antirracistas.

Figura 12 - Arroquy para el suplemento Las 12 sobre el debate por el aborto.

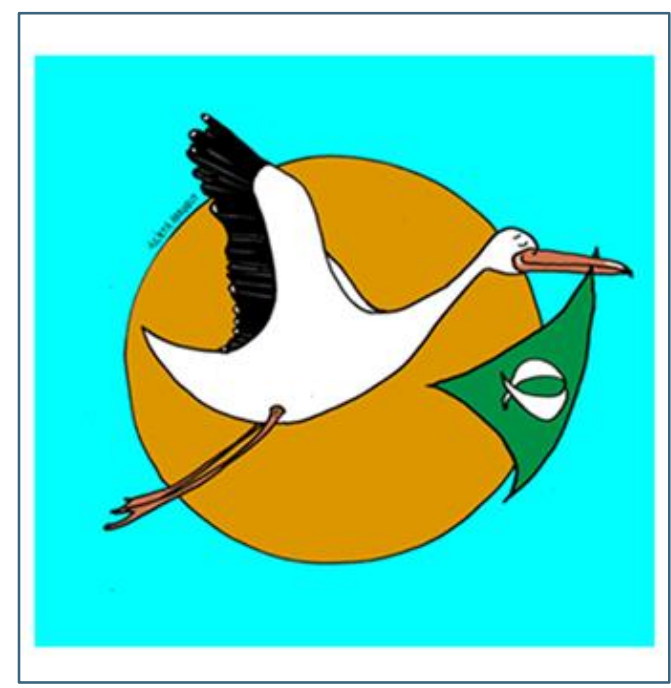

Fuente: ARROQUY (Facebook, 2018) en Nosotras contamos (Acevedo, 2019b p. 42)
Figura 13 - Ro Ferrer en su web (2018) tras la visita al país trasandino de la Campaña por el Aborto Legal.

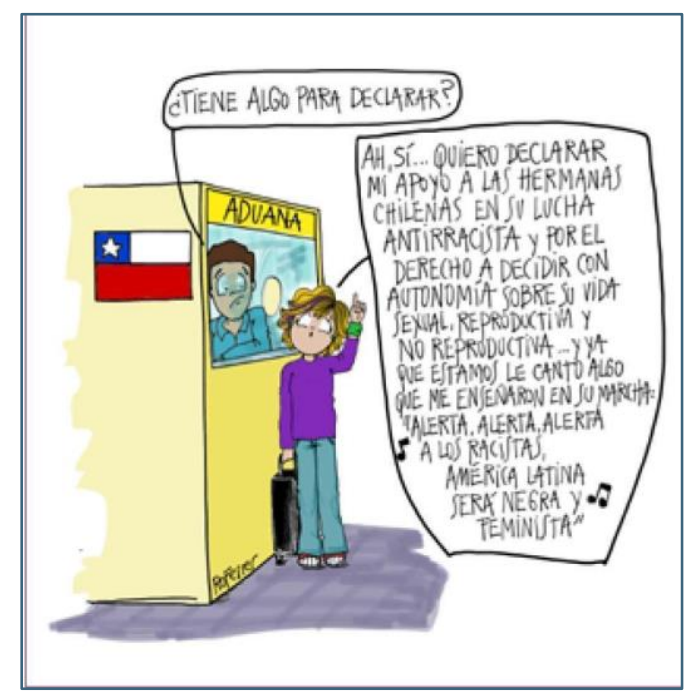

Fuente: FERRER (Facebook, 2018) en Nosotras contamos (Acevedo, 2019b p. 64)

\footnotetext{
22 Sobre el surgimiento de Línea Peluda y las acciones que llevaron a cabo, ver la nota de La Tinta en $\quad$ https://latinta.com.ar/2018/05/linea-peluda-dibujantas-unidas-aborto-legal-segurogratuito/Sole Otero habló de la forma en la que emerge la necesidad de reunirse en la entrevista de Feminismo Gráfico (2018) se encuentra en línea en el canal de youtube de Feminismo Gráfico https://www.youtube.com/watch?v=g1M2bmrdolo
} 
Nosotras contamos. Notas en torno a construir genealogía feminista en el campo de la historieta y el humor gráfico (Argentina, 1933 - 2019)

Mariela Alejandra Acevedo

Los traemos para repensar este arte hecho por autoras y su cruce con la coyuntura actual, la democratización de un espacio largamente hegemonizado por la mirada masculina y hoy ocupado por la risa subversiva de las creadoras.

Figura 14 - La pequeña Esmeralda Mallo Frega (10 años) en una página de "Cómo convertirse en una guerrera" (Mala Praxis Ediciones, 2019) cierra el recorrido del catálogo.

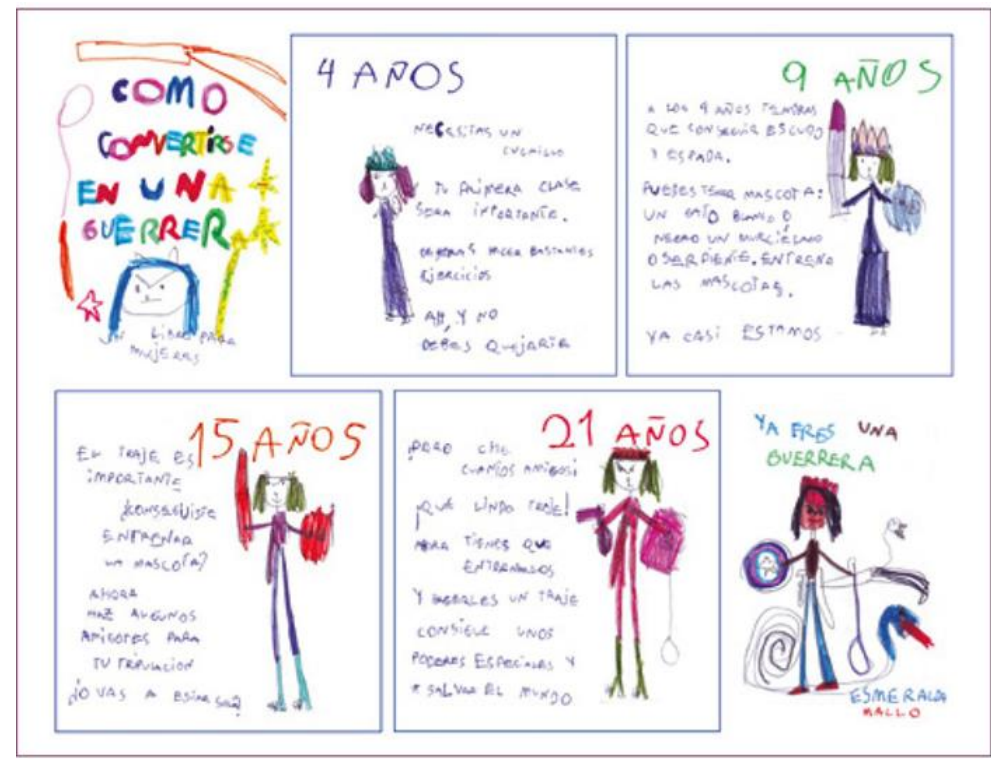

Fuente: MALLO FREGA, 2019 en Nosotras contamos (Acevedo, 2019b p. 14)

Nuestro recorrido llega a su fin. Una última viñeta de humor y una promesa de futuro. Nuestra muestra incluyó el trabajo de Esmeralda Mallo Frega (Fig. 14). La autora es una ultimísima generación que en realidad pertenecería a un quinto período aún no relevado: el de la post escena actual, las pibas que hoy están dibujando y poniéndole imágenes a este universo de luchas. Así, nuestra genealogía está abierta, incompleta, sujeta a revisión y a la colaboración de nuevas líneas que nos permitan completar trayectorias y ponerle humor a nuestra historia, porque no se trata de un registro de eventos ni de un diccionario de autoras. Como señala Alejandra Restrepo (2016, p. 28) "genealogizar exige situar la emergencia de las concepciones e ideas en disputa, en su contexto histórico, social, político y cultural y encontrar el sentido de esas construcciones en la relación de poder en que están inmersos los actores concretos." 


\section{Referências}

ACEVEDO, Mariela. Sextualidades gráficas: sexuación del lenguaje y expresiones de la diferencia sexual en revista Fierro (1984-1992 y 2006-2015). 2019. Tesis doctoral (Doctorado en Ciencias Sociales) - Director Facundo Saxe, Universidad de Buenos Aires, 2019a.

ACEVEDO, Mariela (coord.). Nosotras contamos: un recorrido por la obra de autoras de historieta y humor gráfico de ayer y hoy. Buenos Aires: Feminismo Gráfico, 2019b. Disponible en: https://www.feminismografico.com/muestra-deautoras/. Accedido: 02 out. 2020.

ACEVEDO, Mariela. Humor como espacio de dialogismo sexogenérico: Del canon y el contracanon a la constelación crítica. Revista Artemis, Santa Catarina: UFSC, v. 26, n. 1, jul./dez., 2018. p. 29-52. Disponible en: http://www.periodicos.ufpb.br/index.php/artemis/article/view/42099/21714. Accedido: 02 out. 2020.

ACEVEDO, Mariela; BORGES, Gabriela; SUPNEM, Katherine; MAYOLA, Maira. Historieta feminista en América Latina: autoras de Argentina, Chile, Brasil y México. Tebeosfera, Sevilla, n. 6, 2018. Disponible en:

https://www.tebeosfera.com/documentos/historieta_feminista_en_america_lati na_autoras_de_argentina_chile_brasil_y_mexico.html. Accedido: 02 out. 2020.

ACEVEDO, Mariela. Crítica cultural feminista e Historietas. Notas para una discusión. In: GUTIÉRREZ, María Alicia. (ed.). Entre-Dichos-Cuerpos: coreografías de los géneros y las sexualidades. Buenos Aires: Godot Ediciones, 2016. p. 177207.

EDITORIAL. Revista Totem, Madrid. n. extra 2, p. 3-4, 1978. Especial Mujeres.

LARRONDO, Marina; PONCE, Camila (coord). Activismos feministas jóvenes en américa latina. dimensiones y perspectivas conceptuales. Buenos Aires: Clacso, 2019. Disponible en: https://www.jstor.org/stable/pdf/j.ctvt6rkfs.5.pdf. Accedido: 02 out. 2020.

MÁXIMO, Matías. TRANSita rápido/TRANSita lento. Buenos Aires: Ediciones hormonales, 2012.

MCCAUSLAND, Elisa; BERROCAL, Carla. Repensar a través de la viñeta. In: MCCAUSLAND, Elisa y BERROCAL, Carla (coord). Presentes: autoras de tebeo de ayer y hoy. Madrid: AECID, 2016.

MOI, Toril. Teoría literaria feminista. Madrid: Cátedra, 1988. 
OLIVARES, Cecilia. Glosario de términos de crítica literaria femenina. México: El Colegio de México, 1997.

ORTIZ, Lautaro. Cuando las mujeres reivindican su lugar. Página 12, 11 feb. 2011. Disponible en:

https://www.pagina12.com.ar/diario/suplementos/espectaculos/18-20740-201102-11.html. Accedido: 02 out. 2020.

REGGIANI, Federico. La única verdad es la realidad: apuntes sobre la noción de historieta realista. Cultura, lenguaje y representación revista de estudios culturales de la Universitat Jaume I, Castelló, v. 10, p. 129-137, 2012. Disponible en: http://www.e-revistes.uji.es/index.php/clr/article/view/344/302. Accedido: 02 out. 2020.

RESTREPO, Alejandra. La genealogía como método de investigación feminista. In: BLAZQUEZ GRAF, Norma; CASTAÑEDA SALGADO, Martha Patricia (coord.). Lecturas críticas en investigación feminista. Ciudad de México: Universidad Nacional Autónoma de México, 2016.

RODRÍGUEZ MAGDA, Rosa María. Foucault y la genealogía de los sexos. Barcelona: Anthropos, 2004.

RUIDO, María. Mamá, quiero ser artista! Apuntes sobre la situación de algunas trabajadoras en el sector de la producción de imágenes, aquí y ahora. In: PRECARIAS A LA DERIVA (comp.) A la deriva por los circuitos de la precariedad femenina. Madrid: Traficantes de Sueños, 2004.

SHOWALTER, Elaine. La crítica feminista en el desierto. In: FE, Marina (coord.). Otramente: lectura y escritura feministas. [S.L.]: Fondo de Cultura Económica USA, 1999.

STEIMBERG, Oscar. Semiótica de los medios masivos: el pasaje a los medios de los géneros populares. Buenos Aires: Atuel, 1993.

VAZQUEZ, Laura. Channel №5. Fierro, Buenos Aires: Ed. La Página, n. 52, feb. 2011.

VON REBEUR, Ana. Las mujeres que están dibujadas. Revista Tebeosfera, Sevilla, [entre 1999 y 2001]. Disponible en:

https://tebeosfera.com/1/Seccion/DMH/01/MujeresDibujadas.htm. Accedido: 02 out. 2020.

VON SPRECHER, Roberto. Informe final de Arte desde los géneros y medios de comunicación masivos en Argentina. In: ESTUDIOS Y CRÍTICA DE LA HISTORIETA ARGENTINA. [S.l.: historietas argentinas], 2009. Disponible en: 
https://historietasargentinas.files.wordpress.com/2009/02/vonsprecher_informe final_fna.pdf. Accedido: 02 out. 2020.

\section{Lecturas de consulta (referidas a pie de página)}

ACEVEDO, Mariela. Por más viñetas feministas: Pasado y presente de las creadoras de historietas. Boca de Sapo: Revista de Arte, pensamiento y literatura, Buenos Aires, n. 26, 2018a. Disponible en:

http://www.bocadesapo.com.ar/pdf/05MarielaAcevedo.pdf. Accedido: 02 out. 2020.

BURKART, Mara. Claire Bretécher en la revista HUM® (1979-1984) (O cómo hacer para que el humor gráfico argentino deje de ser una cuestión de hombres). Revista Ártemis; Santa Catarina: UFSC, v. 26, n. 1, jul./dez. 2018. p. 6 - 28.

GUZMÁN, Andrea. Tinta Queer. Nodal Cultura, 23 dic. 2016. Disponible en: https://www.nodalcultura.am/2016/12/tinta-queer/. Accedido: 02 out. 2020.

GUZMÁN, Andrea. Todas para una. Diario Página 12, 23 jun. 2019. Suplemento RADAR. Disponible en: https://www.pagina12.com.ar/201903-todas-para-una. Accedido: 02 out. 2020.ITKIN, Silvia. Mujeres humoristas: hacia un humor sin sexismo. Revista Feminaria, Buenos Aires, n. 2, p. 22-26, nov. 1988.

JUSTO SUÁREZ, Cristina. El mito de la incompetencia tecnológica de las mujeres a través del humor. Debats 85, Barcelona, Verano 2004.

JUSZKO, Paulina. El humor de las argentinas. Buenos Aires: Biblos, 2000.

PÁEZ, Daniela. Las historietistas argentinas: trayectorias, espacios y dinámicas de trabajo desde los '40 a la actualidad. Cuadernos del Centro de Estudios en Diseño y Comunicación. Buenos Aires: Universidad de Palermo, 2020. n. 107. Disponible en:

https://fido.palermo.edu/servicios_dyc/publicacionesdc/cuadernos/detalle_artic ulo.php?id_libro=835\&id_articulo=17110. Accedido: 02 out. 2020.

POGORILES, Leticia. Abre el jueves comicópolis con un dream team de la historieta mundial. Agencia Télam, Buenos Aires, 15 sept. 2015. Disponible en: https://www.telam.com.ar/notas/201509/120059-abre-el-juevescomicopoliscon-un-dream-team-de-la-historieta-mundial.php. Accedido: 02 out. 2020.

VALENZUELA, Andrés. Acá están, éstas son... Diario Página 12, 08 mar. 2018. Suplemento NO. Disponible en: https://www.pagina12.com.ar/100014-aca-estanestas-son. Accedido: 02 out. 2020. 
Todas las ilustraciones pertenecen a sus autoras fueron autorizadas para su reproducción en el catálogo Nosotras contamos. Un recorrido por la obra de autoras de Historieta y Humor Gráfico de ayer y hoy (Buenos Aires, 2019). El catálogo (Acevedo, 2019b) se encuentra en línea en el sitio https://www.feminismografico.com/muestra-de-autoras/

\section{Fuentes originales de las imágenes}

Fig. 01. MAMONE, Julia Inés (2019). Portada para catálogo Nosotras contamos (Acevedo, 2019b)

Fig. 02. Mitzi en Revista Sintonía, Buenos Aires, 1933. (Hemeroteca de la Biblioteca Nacional)

Fig. 03 y 04 RAZNOVICH, Diana; OLLER, Lucrecia. Manual de Instrucciones para mujeres Golpeadas. Lugar de Mujer, Buenos Aires, v.1, n. 1, portada, 1989. Hay versión digital del Manual en http://archive.hemisphericinstitute.org/hemi/en/hidvlprofiles/itemlist/category/133-raz-works accedido 13 de octubre 2020

Fig. 05. BRUNO, Sylvia (1974) en Revista Persona 2, Nov. 1974 p. 51. Hay Versión digital en Archivo digital de revistas América Lee http://americalee.cedinci.org/wp-content/uploads/2016/07/PERSONA-2.pdf accedido 13 de octubre 2020

Fig. 06 ALYEN (2009) viñeta de Mafalda y Libertad publicada originalmente en Baruyeras \#7. Julio, 2009. Hay versión digital en Archivo digital de revistas América Lee http://americalee.cedinci.org/wpcontent/uploads/2017/10/Baruyera_n7.pdf accedido 13 de octubre 2020

Fig. 07 BINDER, Gabriela (2014) Fanpage de ChicaTrans, Facebook.

Fig. 08 EFFÝ MIA, Fanzine TRANSita Rápido/ TRASita Lento (Ediciones Hormonales, autoedición) cedido por Matías Máximo y flia para su reproducción en el proyecto.

Fig. 09 FERNÁNDEZ, Cecilia (2017) en CARRASCO, Adriana (2017) Cuadernos de Militancia Lesbiana \#4, Buenos Aires, marzo 2017. Especial Libertad para Higui. 
Fig. 10 VOLLENWEIDER, Nacha (2019) Viñetas de tortas y bollos. Cómic lesbicos a dos orillas, Pais Vasco. Hay versión digital y libre descarga en https://www.gehitu.org/vinetas-de-bollos-y-tortas-opil-eta-muxilen-binetak-2/ accedido 13 de octubre 2020

Fig. 11 LUNIK, Alejandra (2007). Portada Fierro\#10, Buenos Aires: agosto 2007.

Fig 12 ARROQUY, Julieta (2018) Facebook de la autora.

Fig. 13 FERRER, (2018) Facebook de la autora.

Fig. 14 MALLO FREGA, Esmeralda Mala "Cómo convertirse en una guerrera" Malapraxis Ediciones, Ostende, 2019. 